\title{
THERMOPHYSICAL PROPERTIES AND MICROSTRUCTURE OF MAGNESIUM ALLOYS OF THE Mg-Al TYPE
}

\author{
TERMOFIZIKALNE LASTNOSTI IN MIKROSTRUKTURA \\ MAGNEZIJEVIH ZLITIN TIPA Mg-Al
}

\author{
Petr Lichý ${ }^{1}$, Jaroslav Beňo ${ }^{1}$, Ivana Kroupová ${ }^{1}$, Iveta Vasková ${ }^{2}$ \\ ${ }^{1}$ VŠB-Technical University of Ostrava, Faculty of Metallurgy and Materials Engineering, Department of Metallurgy and Foundry Engineering, \\ 17. listopadu 15/2172, 70833 Ostrava, Czech Republic \\ ${ }^{2}$ Technical University of Košice, Faculty of Metallurgy, Department of Ferrous and Foundry Metallurgy, Letna 9, Košice, Slovak Republic \\ petr.lichy@vsb.cz
}

Prejem rokopisa - received: 2013-10-01; sprejem za objavo - accepted for publication: 2014-11-24

doi:10.17222/mit.2013.196

\begin{abstract}
Generally speaking, magnesium alloys of the $\mathrm{Mg}-\mathrm{Al}$ type are used as structural materials, but their disadvantage lies in their low heat resistance. The addition of suitable alloying elements can be positive, as it makes it possible to achieve good thermo-mechanical properties. For the application of a specific material for thermally stressed cast parts it is necessary to consider the extent of their linear and volumetric changes at elevated and high temperatures. The aim of this paper is to study the behaviour of selected magnesium alloys based on $\mathrm{Mg}$-Al during heat stress conditions in order to simulate real conditions using dilatometric analyses. These properties were evaluated on samples of alloys prepared by gravity casting in metallic moulds. The effect of the metallurgical processing of the alloys on the studied parameters was also investigated.

Keywords: castings, magnesium alloys, thermophysical properties, microstructure
\end{abstract}

V splošnem se zlitine $\mathrm{Mg}-\mathrm{Al}$ uporabljajo kot konstrukcijski materiali, toda njihova pomanjkljivost je, da imajo majhno toplotno odpornost. Dodatek ustreznih zlitinskih elementov pozitivno vpliva na izboljšanje njihove toplotne stabilnosti oz. odpornosti. Pri uporabi nekega materiala, ki bo toplotno obremenjen, moramo upoštevati njegove linearne in volumenske spremembe pri povišanih in visokih temperaturah. Namen tega prispevka je študij vedenja izbranih $\mathrm{Mg}$-zlitin tipa $\mathrm{Mg}-\mathrm{Al}$ med toplotnimi obremenitvami, da bi tako simulirali njihovo vedenje $\mathrm{v}$ realnih razmerah. Njihovo vedenje smo analizirali z dilatometričnimi analizami na vzorcih zlitin, ki so bili izdelani z gravitacijskim litjem v kovinskih modelih. Raziskovali smo tudi vpliv metalurških procesov na izbrane zlitine.

Ključne besede: ulitki, magnezijeve zlitine, termofizikalne lastnosti, mikrostruktura

\section{INTRODUCTION}

Aluminium is the main alloying element in magnesium alloys. Mg-Al based alloys belong to the most widely used group for the foundry industry and they are the oldest of the foundry magnesium alloys. Aluminium is one of the few metals that easily dissolves in magnesium. These alloys may also contain additional alloying elements (e.g., Si, Mn, Zr, Th, Ag, Ce). Their properties are the result of a relatively large area of the solid solution $\delta$ in the equilibrium diagram of a $\mathrm{Mg}-\mathrm{Al}$ alloy and by the possibility of their alloying also with other elements. The most common alloys contain $7-10 \%$ of Al. ${ }^{1}$

Alloys containing more than $7 \% \mathrm{Al}$ are hardenable, and during their hardening a discontinuous precipitate of the $\mathrm{Mg}_{17} \mathrm{Al}_{12}$ phase is formed, the alloys are usually alloyed with small quantities of zinc and manganese. An increasing aluminium content significantly increases the solidification interval and thus also the width of the two-phase zone. Such alloys have during gravity casting a strong tendency to form micro-shrinkages and shrinkage porosities. For this reason the content of $\mathrm{Al}$ in the alloys for gravity casting does not exceed $5 \%$. A brittle intermetallic $\mathrm{Mg}_{17} \mathrm{Al}_{12}$ phase is formed above the solubility limit. The limit of solubility of aluminium at the eutectic temperature is at the amount fraction $x=11.5 \%$ (mass fraction, $w=12 \%$ ), and approximately $1 \%$ at room temperature. As a result of this, the $\mathrm{Mg}_{17} \mathrm{Al}_{12}$ phase plays a dominant role and it decides what the properties will be. ${ }^{2,3}$

\section{PROPERTIES OF MAGNESIUM ALLOYS AT ELEVATED TEMPERATURES}

The use of magnesium alloys in the automotive industry is currently limited to several chosen applications (such as car dashboard, steering wheel, structure of seats, etc.). ${ }^{4}$ The alloys used in these applications are based on the Mg-Al system, for example the series AM and AZ. The alloys based on the $\mathrm{Mg}-\mathrm{Al}$ system are on an industrial scale the most acceptable from the perspective of economics. These alloys offer a good combination of strength and ductility at room temperature. Another advantage is their good corrosion resistance and excellent pourability. The main areas of the increasing use of $\mathrm{Mg}$ alloys for car manufacturers are such components as gear boxes and engine blocks. These applica- 
Table 1: Chemical composition of the used magnesium alloys Tabela 1: Kemijska sestava uporabljenih magnezijevih zlitin

\begin{tabular}{|c|c|c|c|c|c|c|c|c|c|c|}
\hline \multirow{2}{*}{ alloy } & \multicolumn{10}{|c|}{ Element, $w / \%$} \\
\hline & $\mathrm{Zn}$ & $\mathrm{Al}$ & $\mathrm{Si}$ & $\mathrm{Cu}$ & $\mathrm{Mn}$ & $\mathrm{Fe}$ & $\mathrm{Ni}$ & $\mathrm{Ca}$ & $\mathrm{Be}$ & $\mathrm{Sr}$ \\
\hline AZ91 & 0.56 & 8.80 & 0.06 & 0.004 & 0.20 & 0.004 & 0.001 & 0.000 & 0.001 & 0.00 \\
\hline AM60 & 0.07 & 5.78 & 0.03 & 0.001 & 0.33 & 0.003 & 0.001 & 0.000 & 0.001 & 0.00 \\
\hline AMZ40 & 0.14 & 3.76 & 0.02 & 0.001 & 0.34 & 0.003 & 0.000 & 0.000 & 0.001 & 0.00 \\
\hline AJ62 & 0.01 & 5.78 & 0.04 & 0.001 & 0.35 & 0.003 & 0.001 & 0.008 & 0.001 & 2.92 \\
\hline
\end{tabular}

tions require exploitation in operating conditions at a temperature of $150-200{ }^{\circ} \mathrm{C}$. Commercial magnesium alloys of the type AM and AZ do not have these properties, this is related to their poor mechanical properties at elevated temperatures, ${ }^{5}$ and the cause is the low structural stability, and thus the creep resistance. Developments in this area brought about the introduction of new alloys, i.e., $\mathrm{Mg}$-Al-Sr (AJ) and Mg-Al-RE (AE). Magnesium alloys alloyed with rare-earth metals, which do not contain aluminium, are in the long term recognised as one of the most resistant to creep. From the viewpoint of the use of castings made from $\mathrm{Mg}$-alloys at elevated temperatures the volumetric and linear changes of the material are also critical. Their magnitude is determined, among other things, by the chemical composition and by the microstructure of the material (e.g., by presence and share of individual phases, by grain size).

\section{DESCRIPTION OF USED ALLOYS}

For the experimental evaluation both commonly used alloys AZ91, AM60, AMZ40 and the AJ62 alloy were used. All the compared materials were supplied by a Czech manufacturer and Table 1 shows their chemical composition according to the supplier's certificate.

\section{PREPARATION OF THE TEST SAMPLES}

Magnesium alloys were melted in an electric resistance furnace in a metal crucible made from low-alloyed steel. Magnesium alloys are highly reactive thanks to the high affinity of magnesium for oxygen. For this reason the material was treated during melting with an agent having the trade mark EMGESAL. This material in a form of covering and refining flux served for limiting the alloy oxidation and for cleaning the melt of possible inclusions. The castings were produced by gravity casting into the ingot mould made of cast iron, which was prior to pouring pre-heated to a temperature of $450{ }^{\circ} \mathrm{C} \pm$ $30{ }^{\circ} \mathrm{C}$ in order to extend its service life and to achieve sufficient fluidity of the metal. Casting temperatures and operating temperatures were kept in a narrow range in order to achieve as high as possible limitation of the influence of different cooling effects. Part of the melt was treated metallurgically by an agent with the commercial designation MIKROSAL MG T 200, which was based on hexachloretane, and which introduced into the melt the nuclei for crystallisation to achieve the fine- grained structure. This was followed by the manufacture of samples from the castings for an evaluation of the microstructure, as well as samples for a determination of the thermo-physical properties, and test samples for the metallographic analyses.

\section{MICROSTRUCTURE OF THE CAST SAMPLES}

The microstructure of the AZ91 alloy is shown in Figure 1. It is a structure with a share of eutectics and with a significant share of the $\mathrm{Mg}_{17} \mathrm{Al}_{12}$ phase. The addition of the forced crystallisation nuclei did not have any significant effect on this material (Figure 2). A large share of plate-type precipitates is also evident. Figure 3

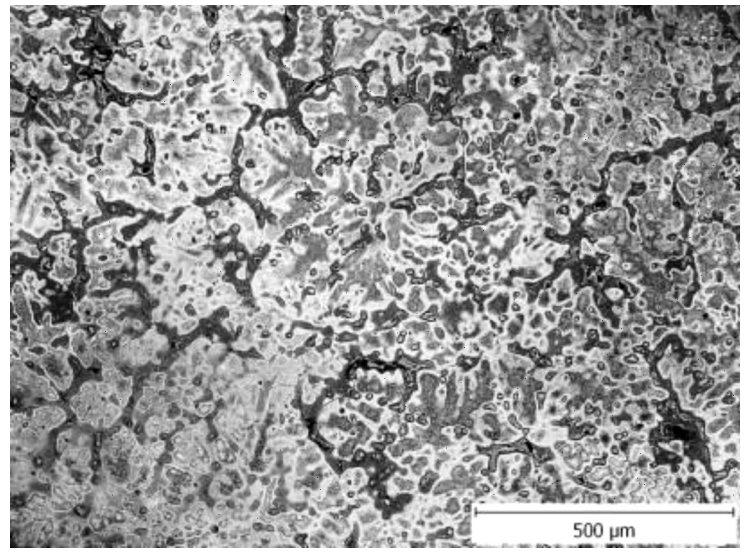

Figure 1: Non-inoculated material AZ91

Slika 1: Necepljena zlitina AZ91

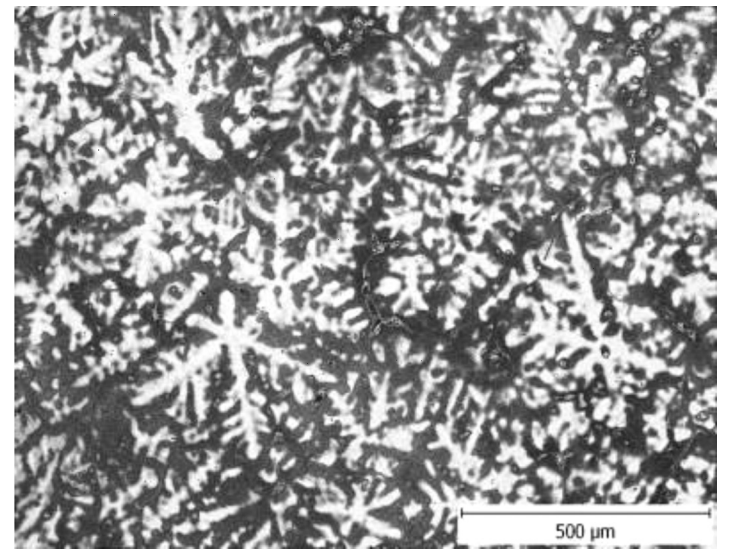

Figure 2: Inoculated material AZ91

Slika 2: Cepljena zlitina AZ91 


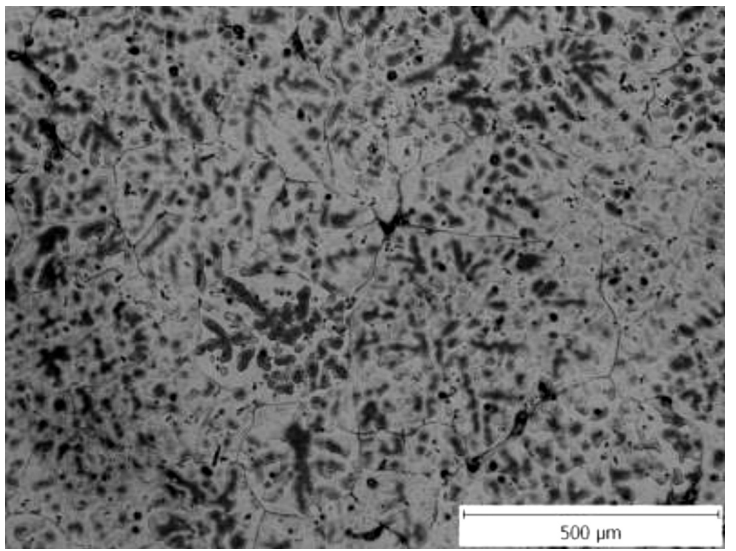

Figure 3: Non-inoculated material AM60

Slika 3: Necepljena zlitina AM60

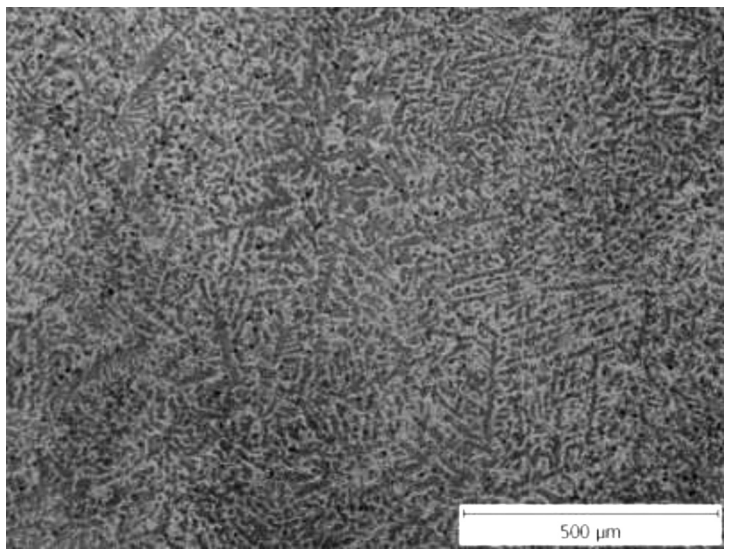

Figure 4: Inoculated material AM60

Slika 4: Cepljena zlitina AM60

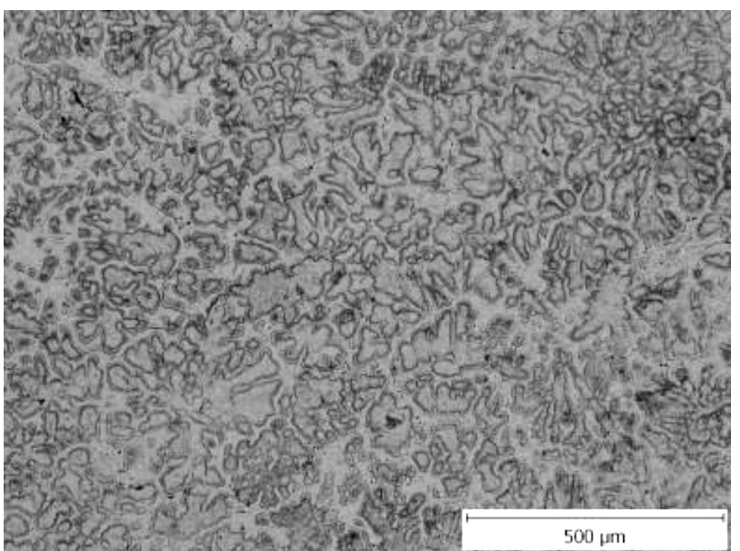

Figure 5: Non-inoculated material AMZ40

Slika 5: Necepljena zlitina AMZ40

shows the microstructure of the AM60 alloy, which consists of a matrix containing a solid solution of $\alpha-\mathrm{Mg}$, a secondary phase of Al-Mn compounds and eutectics. Figure 4 illustrates the structure of the AM60 alloy after the metallurgical treatment (inoculation). The structure is much finer, and its homogeneity was generally improved, which means that it is possible to achieve better mechanical properties.

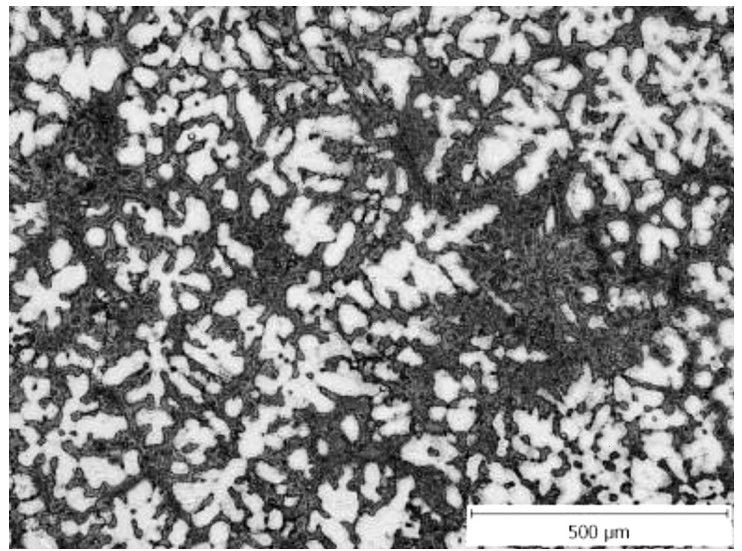

Figure 6: Inoculated material AMZ40

Slika 6: Cepljena zlitina AMZ40

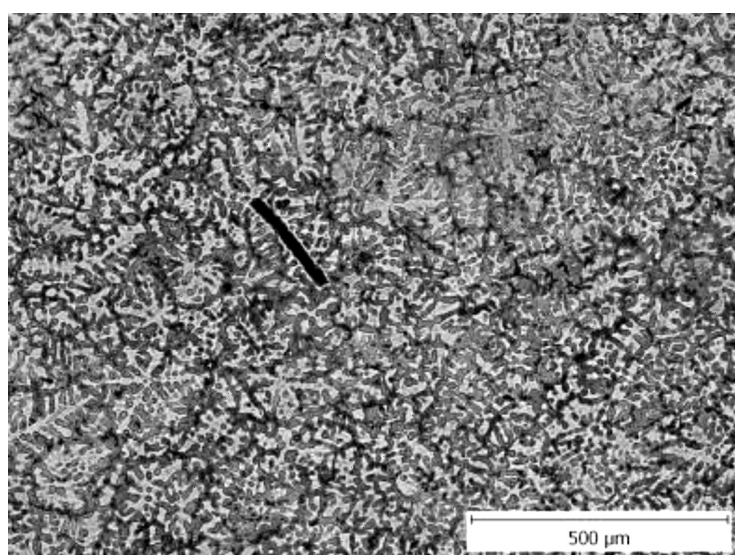

Figure 7: Non-inoculated material AJ62

Slika 7: Necepljena zlitina AJ62

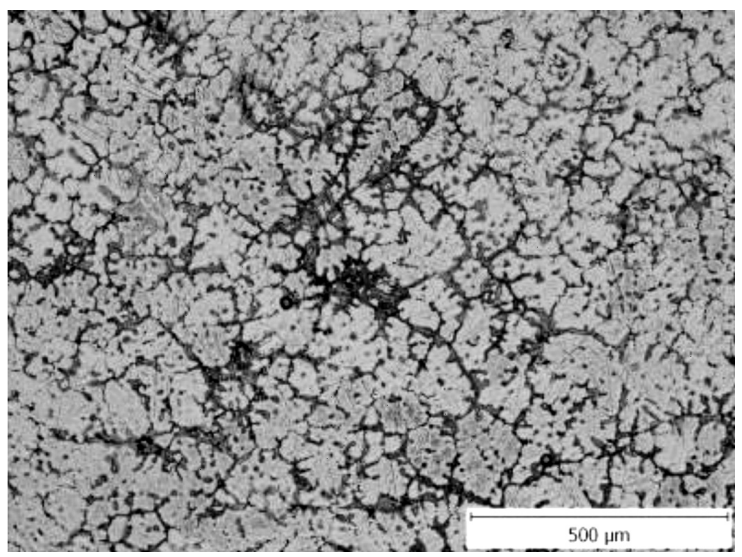

Figure 8: Inoculated material AJ62

Slika 8: Cepljena zlitina AJ62

The effect of inoculation was not manifested in the achieved structure of the AMZ40 alloys (Figures 5 and 6). This alloy is characterised by the low content of alloying elements; its structure is formed by the primary $\alpha-\mathrm{Mg}$ phase and by eutectics without the presence of precipitates.

Figures 7 and $\mathbf{8}$ show the microstructure of the alloy AJ62, consisting of the basic solid solution $\alpha$, as well as 
several types of intermetallic phases, i.e., $(\mathrm{Al}, \mathrm{Mg})_{4} \mathrm{Sr}$, $\mathrm{Al}_{3} \mathrm{Mg}_{13} \mathrm{Sr}$ and very small quantity of $\mathrm{Mn}_{5} \mathrm{Al}_{8}$. In the case of the inoculated alloy (Figure 8) it is possible to find some differences; it is, however, impossible to identify unequivocally the finer structure.

\section{MEASUREMENT OF THE PHYSICAL PROPERTIES}

Dilatometric analyses were performed in order to verify the behaviour of the materials at elevated temperatures. Use of the given material for thermally stressed components is related, among others, to the dimensional stability of the cast part.

Heat expansion (Equation (1)) of the material is usually characterised by the mean temperature coefficient (coefficient of linear expansion):

$$
\alpha_{\mathrm{T}}=\frac{l_{\mathrm{T}}-l_{\mathrm{T} 0}}{l_{\mathrm{T} 0}\left(T-T_{0}\right)}=\frac{1}{l_{0}}\left(\frac{\mathrm{d} l}{\mathrm{~d} T}\right)
$$

where:

$\alpha_{T}$ - coefficient of linear heat expansion

$l_{0}$ - sample length under reference (e.g. laboratory) temperature

$\mathrm{d} l$ - change of the sample length

$\mathrm{d} T$ - difference in temperatures.

The linear heat expansion was measured on the above-described samples with use of a Netzsch DIL $402 \mathrm{C} / 7$ dilatometer. The experiments ran in the temperature interval from $(20 \pm 5){ }^{\circ} \mathrm{C}$ up to $350{ }^{\circ} \mathrm{C}$ with heating and cooling rates of $15.0 \mathrm{~K} / \mathrm{min}$, with a holding time of $30 \mathrm{~min}$ at the maximum temperature (isotherm) in a protective argon atmosphere (99.9999\% Ar) with a constant gas flow of $20 \mathrm{~mL} / \mathrm{min}$. The size of the used samples was as follows: a mean length of $20 \mathrm{~mm}$ and a mean diameter of $6 \mathrm{~mm}$. Samples of the non-inoculated (marked in the name of the sample - as "non") and inoculated materials (marked as "in") were divided into two groups. The first group was used in the as-cast state without previous heat stressing and the second one after their heat stressing $\left(250{ }^{\circ} \mathrm{C}, 30 \mathrm{~min}\right)$ in the argon atmosphere for checking

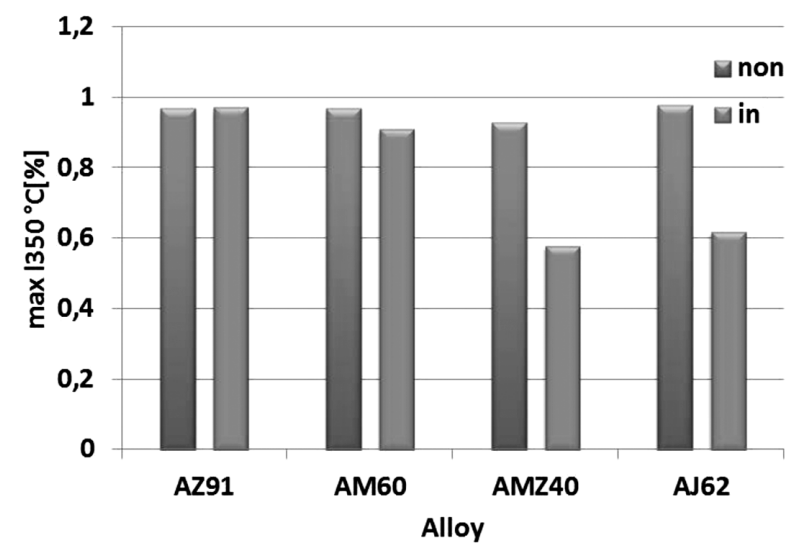

Figure 9: Thermal expansion of material without heat stress Slika 9: Toplotni raztezek zlitin brez toplotne obremenitve the influence of the increased temperature during the stressing of the castings in real conditions.

Table 2 contains the results of the measurements of the coefficient of linear heat expansion $\left(\alpha_{T}\right)$ for the chosen temperature interval $\left((20 \pm 5){ }^{\circ} \mathrm{C}\right.$ up to $\left.350{ }^{\circ} \mathrm{C}\right)$. The table gives the values for the samples without heat stressing $\left(T_{\text {lab }}\right)$ and after heat stressing $\left(250{ }^{\circ} \mathrm{C}, 30 \mathrm{~min}\right)-$ $T_{250}$. Figures 9 and $\mathbf{1 0}$ show the greatest change of length under a temperature of $350{ }^{\circ} \mathrm{C}\left(\max l_{350}{ }^{\circ} \mathrm{C}\right)$.

Table 2: Overview of thermophysical parameters of the Mg alloys Tabela 2: Pregled toplotno-fizikalnih parametrov Mg-zlitin

\begin{tabular}{|l|c|c|}
\hline \multirow{2}{*}{\multicolumn{1}{|c|}{ Specimen }} & $T_{\text {lab }}$ & $T_{250}$ \\
\cline { 2 - 3 } & $\alpha_{T} \times 10^{-6} / \mathrm{K}^{-1}$ & $\alpha_{T} \times 10^{-6} / \mathrm{K}^{-1}$ \\
\hline AZ91 non & 29.6319 & 27.7702 \\
\hline AZ91 in & 28.8887 & 27.3736 \\
\hline AM60 non & 28.7385 & 26.2843 \\
\hline AM60 in & 26.2465 & 26.0252 \\
\hline AMZ40 non & 28.2639 & 18.1402 \\
\hline AMZ40 in & 17.3364 & 17.1782 \\
\hline AJ62 non & 28.8727 & 26.1917 \\
\hline AJ62 in & 18.1686 & 17.5744 \\
\hline
\end{tabular}

In the as-cast state, the highest absolute value of $\alpha_{\mathrm{T}}$ $\left(28.8727 \times 10^{-6}\right)$ was achieved for the AZ91 alloy, and the lowest $\left(17.3364 \times 10^{-6}\right.$ was achieved for the AMZ40 alloy after its metallurgical treatment. It is possible to find from the measured values a correlation between the measured value of the coefficient of linear thermal dilatation and the addition of the inoculant. The structure influenced by the inoculation shows substantially lower values of $\alpha_{\mathrm{T}}$.

A similar effect was observed in the thermally stressed samples of the magnesium alloys. In these cases the achieved values of the coefficient of linear thermal expansion were also the highest in the AZ91 alloy, followed by the AJ62 alloy, while the lowest values were achieved in the AMZ40 alloy.

The values of the maximum length change achieved at the temperature of $350{ }^{\circ} \mathrm{C}$ also correspond with these

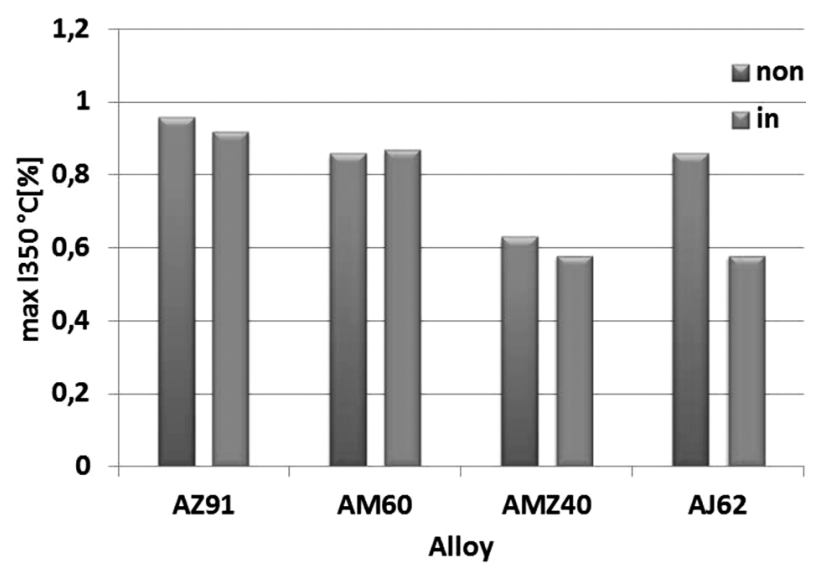

Figure 10: Thermal expansion of material after heat stress Slika 10: Toplotni raztezek zlitin po toplotni obremenitvi 
results. The positive impact of the inoculation was unequivocally demonstrated here, particularly in the case of the AMZ40 alloy. In case of the samples without thermal stressing (Figure 9) it was possible to note a considerable difference between the non-inoculated and inoculated materials. On the other hand, in the case of the thermally stressed samples (Figure 10), this difference is much smaller. It is therefore possible to assume a distinct influence of a possible heat treatment on these properties.

\section{CONCLUSIONS}

This study was focused on an evaluation of the thermophysical properties and microstructure of the magnesium alloys AZ91, AM60, AMZ40 and AJ62. On the basis of the realised experiments, it is possible to see a positive impact of the inoculation on the achievement of the smaller dilations of materials, which are important from the perspective of the use of casting for heatstressed parts. The lowest values of the coefficient of linear thermal expansion and the maximum value of expansion at the temperature of $350{ }^{\circ} \mathrm{C}$ were achieved with samples of the alloys AJ62 and AMZ40, which were metallurgically processed. Despite the high cooling effect of the metallic mould, the positive effect of inoculation on the evaluated properties and microstructure of majority of the magnesium alloys were visible.

\section{Acknowledgements}

This work was conducted within the frame of the research project TA02011333 (Technology Agency of the $\mathrm{CR}$ ).

\section{REFERENCES}

${ }^{1}$ M. J. F. Gándara, Mater. Tehnol., 45 (2011) 6, 633-637

${ }^{2}$ B. L. Mordike, T. Ebert, Materials Science and Engineering A, 302 (2001) 1, 37-45, doi:10.1016/S0921-5093(00)01351-4

${ }^{3}$ S. Roskosz, J. Adamiec, M. Blotnicki, Archives of Foundry Engineering, 7 (2007) 1, 143-146

${ }^{4}$ E. Adámková, P. Jelínek, S. Študentová, Manufacturing Technology, 13 (2013) 3, 255-262

${ }^{5}$ P. Lichý, M. Cagala, J. Beňo, Mater. Tehnol., 47 (2013) 4, 503-506 